\title{
Microfinance communication for group saving and loan sustainability, a case study of Tabur Puja scheme in Posdaya, Jakarta
}

\author{
A. Witono ${ }^{1, *}$, A. Venus ${ }^{2}$ \\ ${ }^{1}$ Akademi Sekretari \& Manajemen Dharma Budhi Bhakti, Jakarta, Indonesia \\ 2 Department of Communication Management, Faculty of Communication Science Universitas Padjadjaran, Indonesia \\ *Corresponding author: andikawitono@yahoo.com ; venusantar@yahoo.com
}

\section{ABSTRACT}

Tabur Puja Scheme was founded in 2012, with the intention to to provide loan for micro enterpreuner in Posdaya (Pos Pemberdayaan Keluarga) Community which was funded by Damandiri Foundation. The community consist of maximum 100 members, under the supervision of 4 to 6 Coordinators in one Rukun Warga (Citizen Association).

For the past 4 years, Tabur Puja Scheme nonperforming loan is constantly below 5\%. Surprisingly it managed by activists in the community, which is far from professional financial personnel. They work as part timer.

It would raise the following questions, first, how could and why do they maintain such performance and become sustainable group saving and loan? Second, how do communications play important role to keep intact all the members and to maintain good relations as well as loan performance.

This research was being done in 2 Posdaya in Jakarta area, namely Posdaya Soka in Kebayoran Lama, and Posdaya Melati in Bukit Duri area. The method employed is case study in order to answer the how and why questions. By using this approach, several aspects which contribute to the success of sustainable group saving and loan could be reviewed to support the final conclusion of this research. Johari windows, Tuckman group development theory and Interaction symbolic are being used to frame the research using communication science perspective.

Keywords: Microfinance Communications, Tabur Puja Scheme, Posdaya Communities, Sustainability

\section{INTRODUCTION}

Tabur Puja is a short term of Tabungan dan Kredit Pundi Sejahtera. This scheme is group saving and loan which easily accessed by Posdaya members for less well off families to start an economic activities useful for the elimination of poverty, strengthened by the desire of the Posdaya family member to save (Murnijati, 2015). In Jakarta, there are more than 11,000 Posdaya, but only 38 of them are appointed to run Tabur Puja scheme since 2012. Total members are reaching 4,197 people, spread in South and East Jakarta. Amazingly the non performance loan is $2 \%$ per June 2016. To connect Tabur Puja members or debtors, Posdaya Leaders manage to have a face-to-face communication for at least once in a month when debtors pay their installment. Besides, as they live nearby, when a debtor is unable to pay the installment, the Coordinator and Posdaya Leader will pay a visit to debtor's house.

Posdaya is a short term of Pos Pemberdayaan Keluarga or Family Empowerment Post. It is a model of community empowerment in Indonesia which has been implemented since 2006. It is a forum for gathering, advocacy, communication, information, education and also could be developed into a strengthening of the coordination of activities of family functions in an integrated manner. The primary functions are expected to allow families to be able to develop themselves into a prosperous family and can face the challenges for the better future. Posdaya activities are located in the residential neighborhood that is at the level of Rukun Tetangga (RT), Rukun Warga $(R W)$, hamlet or village. Posdaya aims to enhance family and community welfare, and thus alleviating poverty (Murnijati, 2012). The activities are varied, from Posyandu (Integrated Service Post), PAUD (Early Age Education), Kebun Bergizi (Nourishing Garden), etc. All those activities are 
supported by systemic training and easily accessed working capital through Tabur Puja scheme.

Each Posdaya has at least 4 to 6 sub-groups. Every subgroup has 15 to 27 members. Each Posdaya has its Leader, and the leader has assistants who are the coordinators of those subgroups. The organization is being sliced into small groups to enable control by each subgroup leader towards its members. Bear in mind that these groups have responsibility towards their members performance both in business as well in disciplinary towards debt repayment.

Prof. Dr. Hayono Suyono, as the Chairman of Damandiri Foundation at that time, founded Posdaya, and his position has been replaced by $\operatorname{Dr}(\mathrm{HC})$ Subiakto Tjakrawerdaja since the beginning year 2016. This program has been established as part of community development program planned by Bogor Agriculture University for the empowerment of communities living around the campus (Muljono, 2013). The scheme intended to enable poor people to have access to receive soft loan capital. There are no collateral needed, however if one of the members cannot pay the installment, then the rest of the members would bear the responsibility. This is called tanggung-renteng. The first loan is Rp2 million, and if the business goes well, then the debtor could increase the loan amount up to Rp31. million.

Most people would think that the risk is low, and it is only a hibah (grant), which means that there is no obligation to pay back. There are cases occured when the business went bankrupt, maybe the cattlefishes which they breed went dead, or the cows were sick and died, or the food that they sell were not sold well, so they are unable to pay the debt. If these had happened, then it is more difficult to settle the case. But if the prediction is there, and an open communication is being maintained, then it can be resolved and minimized at an early stage. Maintaining communication between members, Credit Assistant/Field Supervisor, and Cooperative management, will assure that potential problems can be discussed and avoided. Moreover, when higher education institutions involved, then it would be easier to resolve the issues.

The development of Microfinance Institution itself began in 1998 during the Asian monetary crisis which hit big corporates and banking badly. From then, only in 2013 Government finally issued a constitution for Microfinance Institution under Law No. 1/ 2013.
Cooperative and Perseroan Terbatas (PT) are considered as Microfinance Institutions. Therefore, Cooperative as the legal entity distributes micro scale loan to its members through Posdaya communities. In Jakarta, Posdaya which implemented Tabur Puja scheme were under Sudara Indra Cooperative (Koperasi Sudara Indra). All saving and loan activities of Posdaya Communities members were registered through this Cooperative.

Based on Sustainable Development Goals, in order to eradicate poverty, microcredit could help to develop microbusinesses. But the most important thing, due to lack of management ability to manage their microbussiness, small groups in Posdaya would effectively monitor the progress. Aside of providing loan, the groups would also accomodate savings. Communication again plays important role on how Coordinators motivate team members.

The link of Tabur Puja scheme between Cooperative and Posdaya is shown by the following diagram:

\section{Figure 1. Tabur Puja Method of Credit , Installment, Reporting and Mentoring (Murnijati, 2015)}

\section{Communication Involvement}

Diagram 1 shows the communication flow from Cooperative to Posdaya and Posdaya to Posdaya Group of microbusinesses which are members of Tabur Puja Scheme. Coordinators or Promotors are universities which provide Tabur Puja members with technical assistance, in this case Universitas Trilogi and Universitas Pancasila. To run Tabur Puja Scheme, Posdaya management who consist of chairman, treasurer and secretary had to choose 100 members only. To handle these 100 members, there are 4 to 6 group coordinators. Each group consists of 15 to 27 members. With such small groups, it would be easier for group coordinators to handle communication with their members. The communication will monitor the progress of their members microbusinesses activities.

Diagram 2 shows the communication flow of every party involved. Each party had to ensure that communication is being done in a timely manner. Field Supervisor who visits every week to Posdaya on cash day service will meet members who will do the transaction for both saving and loan. Subgroup discussion between Subgroup Coordinator and members will occur based on an agreed 
time schedule. However it is a must that they meet once in a month with all the subgroup members.

Cooperative Manager should attend the monthly coordination with Posdaya Leaders and visit periodically. A random visit to members' business location is also required, to ensure the progress of members' business as well as to verify the report given from Posdaya Leader as well as Subgroup Coordinator.

Figure 2. Developing and Monitoring System Mechanism Tabur Puja Scheme Through Posdaya

\section{METHOD}

This research used case study approach to reveal the case in Tabur Puja Scheme at Posdaya Soka in Rukun Warga 12, Kelurahan Kebayoran Lama Selatan, Kecamatan Kebayoran Lama, South Jakarta and Posdaya Melati in Rukun Warga 11 Kampung Melayu Kecil, Kelurahan Bukit Duri, Kecamatan Tebet, South Jakarta. Depth interview was conducted with Posdaya Leaders, Subgroup Coordinators, Tabur Puja Manager in Sudara Indra Cooperative, Credit Assistant/Field Supervisor, Chief of Tabur Puja Micro Finance Consultant, and Representative from Damandiri Foundation. The interviewed were being done in each Posdaya.

Each small groups have to manage regular meetings at least once in a month, to receive updated information for Tabur Puja members activities. For example, one of the family members is sick and required extra expenses for medical service. Therefore, budget for loan installment will be used.

Symbolic interactionism, Tuckman Group Development Theory and Johari Windows are being used to view the communication phenomenon in this microfinance case. Symbolic interactionism is being used to reveal how social interaction played important role for Posdaya Leaders and Coordinators to enable them to understand the members perspectives. Johari Windows (Wood, 2013) is being used to view how Posdaya Leader and Coordinators have to work creatively to stimulate their team members to avoid bad debt in their microbusinesses. Tuckman group develompent is used to overcome problems occured in the group conflict.

Figure 3. Source: Charon (2007: 41)

\section{RESULTS}

Tabur Puja scheme is being socialized and distributed through face-to-face interaction, from Cooperative Manager of Tabur Puja to Posdya Leader and then goes through Coordinator in Subgroup. There are Credit Assistants to help Cooperative Managers of Tabur Puja to collect the information needed from the members, and some forms that members had to fill prior to submit their request for the loan, and has to be signed by the rest of the members. For example, if within the subgroup there are 15 members, then one request for loan will require the other 14 members to sign the request form. Coordinator of subgroup plays an important role to collect the signature as well as ensuring that the debtor will be fully responsible for the loan. Principally, if the business goes well, then the debtor will be able to pay the installment. On the contrary, if the business goes bankrupt, then the debtor will be in financial difficulties. At the end, debtors will be suffering from debt as one cannot pay the installment of the loan.

In the view of symbolic interaction, how the communication in Posdaya, especially for Tabur Puja scheme, works started within the social interaction between the community in the same residential neighborhood (Rukun Tetangga/RT), which is then expanded to maximum of hamlet or village (Rukun Warga/RW). Posdaya Leader is mostly the wife of residential neighborhood head or hamlet head. They are the ones who concern about social problems occured in their surrounding, together with other members from a group of Posdaya. With several social activities, then Damandiri Foundation decided to enhance Posdaya capabilities to handle saving and loan for its members who own microbussinesses. However, Tabur Puja scheme has its rule and regulation to be followed, because this facility was provided without any collateral. The human relationship is the guarantee of this loan. Therefore, each member has to connect with the rest of the team member to ensure supports are given, and sustainability of the loan is being controlled.

By doing this, the Leader of Posdaya and the subgroup Coordinator had to know in detail about their members, such as what is the specialties of their members, whether making food such as onde-onde, or risoles, bir pletok, the traditional drink of Betawi, keripik pisang or meat ball (bakso), the favorite food of the community. It is Posdaya Leader and her subgroup coordinators task to 
find out the actual habit of the members and understand the need to grow their microbusinesses.

In minimum, Posdaya Leader would meet members in every cash service day, which open once in a week, in a certain day and time agreed by members. Other than that, the subgroup coordinator will arrange the time of reguler meetings in monthly basis at the time and place greed by the members.

The topic of discussion is the updating information of the progress that Posdaya has made. For example, how many members request loan, and how many members saved, and whether new members have been registered. Problems occured in Posdaya's saving and loan activities are also being discussed, such as compulsory saving and voluntary saving, due date for members current loan, and other problems related to Posdaya development. It is a must to attend such meetings - those who can not attend the meeting will receive sanction. It is admitted by Posdaya Leaders and subgroup Coordinators that their members may have some excuses not to attend the meeting because of their activities. Some food or street vendors in traditional market claim that if they leave their shop, then they will loose some customers.

However, it is the rule and regulation for Tabur Puja scheme to have a face to face communication and discussion among members to ensure that the integrity and the principle of "gotong-royong" is still being kept. Information will be updated through face-to-face interaction or other media such as Whatsapp's or Facebook, and SMS (short message service). In this way, the members will be connected to one another. The point of togetherness differentiate Tabur Puja Scheme from traditional money lender, aside for the interest rate.

Subgroup Leader and/or Posdaya should visit team members regularly to see the progress of their business. Based on the manual of Tabur Puja Scheme, the developing and monitoring communication system is to ensure the following:

a. To detect problems arising from the member's business activities at early stage, so as to find solutions as soon as possible.

b. Keeping the loan can be repaid in a timely manner in accordance with the agreement.

c. To ensure that any loans made to members actually utilized for members business interests.
Tabur Puja scheme also accommodate saving, therefore it is not a matter of financial literacy for the microentrepreneurs only, but also on how they should learn to save their money and spent on what is really needed. Therefore, if there are problems incurred, their savings will be useful to resolve financial problems. This is where the role of Posdaya Leader as well as Subgroup Coordinator is needed to understand their members background, and explore the ability to optimize the member capability. In this issue, Johari Window provide a perspective on how those Leaders had to bear members behavior to explore their maximum capacity in order to have a steady income and bring positive impact to their family life. Better welfare would create a stronger economic power in this country.

Meanwhile, Tuckman group development is to accommodate the conflict occur among members. When a member has difficulties to pay the installment, then other members had to conduct a meeting to decide whether or not the installment will be paid by using Tanggung-Renteng fund.

\section{CONCLUDING REMARK}

Based on the above research and observation, for microfinance the need to have face-to-face communication is unavoidable. A personal touch between Posdaya Leader, Subgroup Coordinators, Credit Assistant/Field Supervisor, and members are being shared from one another. Close monitoring would help microbusiness to develop and enhance the ability as well as being sustainable in order to have a steady income.

However, the communications for developing and monitoring the progress throughout the installment period is not an easy task. Manual and standard operation procedure had to be prepared in order for the appropriate data and the communication effect to have results and provide progress to a better life. Routine meetings, random visits, face-to-face communication are constantly needed. By doing this, the progress of the business activities of the debtors are closely monitored. There are no space for bankruptcy, therefore the empowerment of the grass root of Posdaya member should be strengthened.

\section{ACKNOWLEDGEMENT}

Author would like to thank Mrs. Anna Murnijati and Mr. Karel Palallo who have contributed opinion in regards of 
Tabur Puja Scheme in Posdaya as well as issues and system applied in microfinance.

\section{REFERENCE}

[1] Effendy, Onong Uchjana, Prof. ,Drs., M.A., Ilmu Komunikasi, Teori dan Praktek. Rosda: Bandung. 2013

[2] Charon, Joel M., Symbolic Interactionism: An Introduction, An Interpretation, An Integration, Ninth Edition. New Jersey. Pearson Prentice Hall. 2007.

[3] Majalah Keluarga Mandiri GEMARI Edisi 138/Tahun XIII. Juli 2012

[4] Murnijati, Anna. Family Economic Empowerment Through Posdaya with help of Tabur Puja, Third Edition. Damandiri. Jakarta. 2015.

[5] Suyono, Haryono. Prof. Dr. dan Haryanto, Rohadi. Dr. MSc. Buku Pedoman Pembentukan dan Pengembangan Pos Pemberdayaan Keluarga. Balai Pustaka, Jakarta. 2013.

[6] Muljono, Pudji. The Role of Posdaya in Shaping Community empowerment: Case Study at Cikarawang Village, Bogor, Indonesia. Asian Journal of Humanities and Social Studies Vol. 01-Issue 05, Dec 2013, 225-232.

[7] Tuckman, Bruce. Psychological Bulletin, Vol. 63, No. 6, 1965. 384-399 p.

[8] Witono, Andika. Proceeding PACA 2014. Tanggung renteng Culture: A Microfinance Communication Perspective ( A case study at Posdaya, Jakarta). Universitas Padjadjaran. Bandung. 2014.

[9] Wood, Julian T., Komunikasi Interpersonal: Interaksi Keseharian Edisi 6. Salemba Humanika. Jakarta. 2013. 


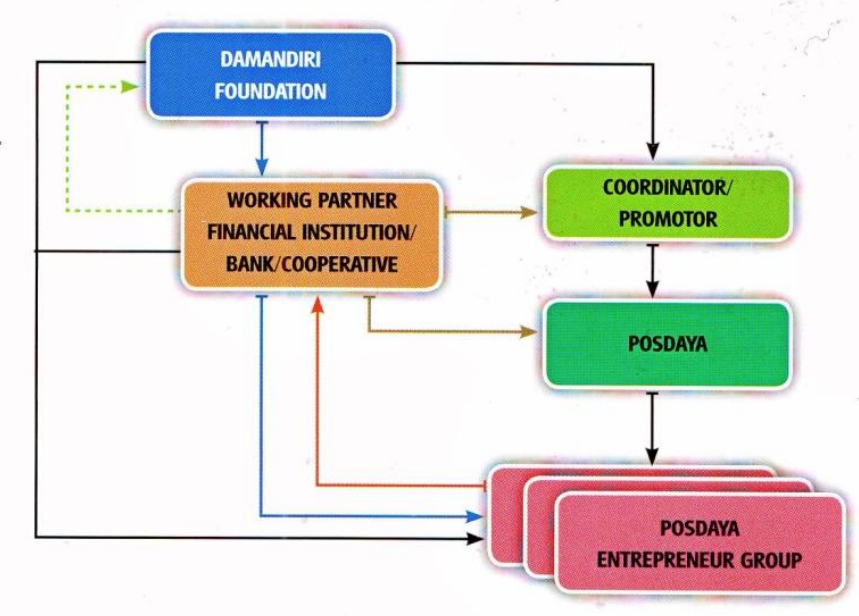

NOTE :

\begin{tabular}{|l|l}
\hline$\longrightarrow$ & Distribution of The Tabur Puja Credit \\
\hline$\longrightarrow$ & Loan Installment (Principal + Interest) \\
\hline$\longrightarrow$ & Promotion (Direct and Indirect) \\
\hline$\longrightarrow \cdots$ & Periodic Reporting \\
\hline & Cooperation \\
\hline
\end{tabular}

Figure 1. Tabur Puja Method of Credit , Installment, Reporting and Mentoring (Murnijati, 2015)

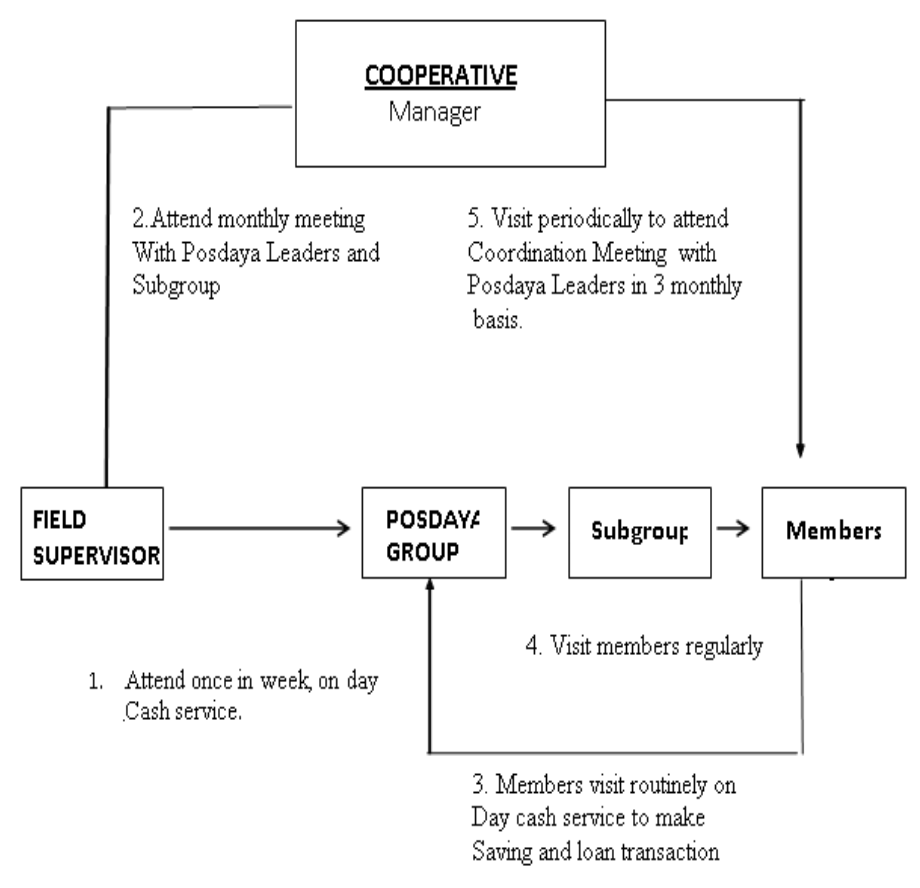

Figure 2. Developing and Monitoring System Mechanism Tabur Puja Scheme Through Posdaya 


\footnotetext{
Social Interaction

$\square$

Forms a reference group that

$\zeta$

Creates a perspectives that, in turn

5

Can be used by the individual to define a situation that, in turn,

Leads to action by the individual and other that, in turn

Alters the individual's perspective and then his or her definition that, in turn

Influences ongoing action by the individual
}

Figure 3. Source: Charon (2007: 41) 